\title{
The Development of Student Worksheets Based on Discovery Learning Subtema Utilizing Natural Wealth in Indonesia in Fourth Grade Elementary Schools
}

\author{
Mutiara Delima $^{1 *} \quad$ Darsono $^{2} \quad$ Alben Ambarita $^{3} \quad$ Munaris $^{4}$ \\ Faculty of Teacher Training and Education, University of Lampung \\ St. Soemantri Brojonegoro No.1 Gedung Meneng Bandar Lampung 35145
}

\begin{abstract}
The purpose of this study is to develop and describe the appropriateness, attractiveness, and effectiveness of developing student worksheets based on discovery learning on the sub-theme of utilizing natural resources in Indonesia in fourth-grade elementary schools. This type of research is research and development refers to Borg and Gall theory. The study population was fourth-grade students in the Elementary School in Way Halim District, and the sample was determined by a purposive sampling of 92 students. Data were collected through observation sheets, questionnaires, and test questions. The data analysis technique used the n-Gain test to determine effectiveness. The results showed that the discovery learning-based development product that was produced was effectively used in the learning process for fourth-grade students on the subtheme of natural resource utilization in Indonesia's fourth grade Elementary School. This is proved by the increase in student learning outcomes after using worksheets based on discovery learning.
\end{abstract}

Keywords: Worksheets, Discovery Learning, learning outcomes.

DOI: $10.7176 / \mathrm{JEP} / 10-35-14$

Publication date: December $31^{\text {st }} 2019$

\section{INTRODUCTION}

Education is a process of change that occurs continuously towards better progress. This is because intelligent or educated people will be able to make a positive contribution to the country. However, it should be remembered that education will succeed to the maximum when every element of education from the bottom up is always oriented towards the national education goals by taking into account the components in learning. Education includes the main vehicle for developing human resources that are carried out systematically, programmed, and tiered.

According to Bruner (Balim 2009: 2) shows that every individual has a willingness to learn and this will have to be used in activities such as having to increase curiosity and students directly learn and find knowledge. Through education, a person can develop his potential that is needed to adjust and follow the development of science and technology which from time to time is growing rapidly.

The curriculum is an element of educational resources. Therefore, the curriculum provides a significant contribution to realizing the process of developing the quality of potential learners. This is by the objectives to be achieved in the application of the Curriculum 2013 is the students can search for and find concepts from the material being studied so that they do not merely provide answers to the problems found. Curriculum 2013 applies to integrated thematic learning.

According to Fogarty (1991: 76), The integrated curricular model represents a cross-disciplinary approach similar to the shared model. The integrated model blends the four major disciplines by setting curricular priorities in each and finding the overlapping skills, concepts, and attitudes in all four. The learning process in Curriculum 2013 is directed at making students able to think analytically in decision making, not mechanistic thinking (routinely just listening and memorizing only). But the reality in the field The learning process is still oriented to how students master and memorize information and lack of opportunities to develop their thinking skills (Trianto, 2010: 5-6).

Learning activities cannot be separated from the involvement of teaching materials. According to Hamalik (2014: 139), teaching material is an important part of the teaching and learning process, which occupies a position that determines the success of teaching and learning related to the achievement of teaching objectives, and determines teaching and learning activities. Everything that the teacher uses to convey a lesson can be classified into teaching materials. Considering the importance of teaching materials in teaching and learning activities, it is necessary to pay attention to the quality both in terms of content, language, graphic elements, and illustrations.

The involvement of teaching materials in the learning process is very important because teaching materials provide direction to the learning process. Through teaching materials, teachers will be easier to teach and students will be more helpful in understanding the material. Teaching materials can be made in various forms according to the needs and characteristics of the teaching material presented. According to Amri (2013: 95: 104), the types of teaching materials based on their packaging can be divided into (a) textbooks, (b) learning modules, (c) textbooks, 
(d) Student Worksheets, (e) instructions practicum, (f) handouts. One alternative that can be done by the teacher so that students can play an active and independent role in developing their knowledge is by using Student Worksheets.

According to Sands \& Ozcelik (Celikler 2010: 43) states that: Worksheets are defined as the fundamental tools containing required process steps and helping students to configure the knowledge and at the same time provide a full participation of the entire class in the activities. Student worksheets are also defined as printed teaching materials in the form of sheets of paper containing material, summaries, and instructions for the implementation of tasks to be done by students that refer to the basic competencies achieved according to Prastowo (2015: 204). In line with this Saka (Toman 2013: 174) argues that "Worksheets are one of the teaching methods which can be done individually or in group work and enable conceptual development." Learning that involves students actively will be more effective if the teacher is able to use student worksheet that is in accordance with the characteristics of students. The use of student worksheets is expected to help improve effectiveness and fluency in the learning process so that learning objectives can be achieved optimally.

Besides the discovery learning model learning is one part of discovery learning that involves many students in teaching and learning. In addition, students also learn to solve problems independently and develop thinking skills, because they must analyze the information they have obtained. Discovery Learning is also called guided discovery which is a learning model where students are told to get a conclusion from a series of activities carried out so that students seem to find their own knowledge, Supeno (2008: 218). According to Abruscato \& DeRosa (2010: 42) revealed that "Discovery Simply means coming to know before. Discovery happens when a child uncovers new information or gleans new insight about how to approach a problem or task and then completes the tas kor solves the problem on hero his own. It is an individual and personal experiences. Classroom don't; discovery: individual children do". Discovery learning is an important component in a constructivist approach that has a long history in education. According to Suryosubroto (Samsul 2016: 115) shows that one of the teaching methods widely used in schools that have been developed is the discovery method. Discovery learning is also a model that encourages students to come to a conclusion based on their own activities and observations Gumay (2009: 2).

Based on these assumptions, it is very necessary student worksheet teaching materials that are able to explore student competencies based on learning outcomes through discovery learning based teaching materials. This is in line with the results of observations at the Elementary School that conducted the 2013 curriculum in Way Halim Subdistrict. The average value of the summative test was still below the minimum completeness criteria.

Based on data analysis on schools that implement the 2013 curriculum in Way Halim sub-district, the fundamental problem in learning activities at this time is that most teachers have not been able to use and develop student worksheets that can involve students actively and creatively, students seem to be passive in learning activities, how to teach teachers that always goes one way and student worksheets that are used monotonously make learning achievements of many students who have not reached the minimum completeness criteria. This achievement is the result of learning conditions that are still conventional in nature.

Student learning outcomes and meaningfulness is something that needs to be considered in the learning process, based on the results of the questionnaire revealing the needs of teachers and students, especially in primary schools and in the end the teachers in schools implementing the 2013 curriculum agree if a student worksheet is developed that can help students take an active and creative role in learning to be more easily understood. With a student worksheet, it can help students understand the material to be delivered. An educator must be able to prepare a capable student worksheet and can be used as guidelines and references in the learning process in class.

Based on the facts that have been described above, then steps are taken to improve with appropriate solutions in an effort to improve student learning outcomes by considering the characteristics and competencies of students, it is felt necessary to develop instructional media in the form of teaching materials. There are several types of teaching materials namely printed books, modules, textbooks, student worksheets and others. Teaching material that will be developed in the form of student worksheets. Student worksheet is an activity sheet that is used to assist teachers in providing optimal learning. Even though the material that fits the curriculum is quite abundant does not mean we don't need to develop the material ourselves. Because for students, often too much material makes them confused, for that teachers need to make student worksheets as a guide for students.

This study refers to the findings by Fibonacci (2014) showing that research development of teaching materials improves student learning outcomes. The effectiveness of N-gain is 0.68 (medium) higher than before using teaching materials and students have a positive response to the development of teaching materials. In addition, this study also refers to the results of Ozman's research (2011). The results of this study indicate that learning using student worksheets is more effective than classes taught by conventional methods, this is evidenced by the significant difference in learning outcomes between the control class and the experimental class.

Another consideration is that student worksheets that are developed by other people are often not suitable for students. Reasons for incompatibility, for example, social environment, geographical, cultural, and others. For this reason, self-developed student worksheets can be adjusted to the characteristics of students as targets to be able to 
answer or solve problems or difficulties in learning.

\section{RESEARCH METODS}

The type of research using research and development refers to the theory of Borg \& Gall (1989:782) on ReasearchBased-Development according to the purpose of research, namely research procedures with the aim of developing and validating educational products developed. Research and development are carried out only not until all stages, because of limited resources. The study population was fourth grade students of the State Elementary School Way Halim Sub-district, Bandar Lampung who had implemented the 2013 curriculum. and the sample is determined by purposive sampling of 92 students in SDN 2 Perumnas Way Halim and SDN 1 Jagabaya. Considering that SDN 2 Perumnas Way Halim and SDN 1 Jagabaya are models for implementing the 2013 Curriculum.

Data collection tools for the development of integrative thematic learning tools using a questionnaire, namely the validation of material experts, design, and language. Learning outcomes are obtained from the results of the pretest and posttest learning using discovery learning-based student worksheets, the test instruments used are valid and reliable, and consider the level of difficulty and different power of the questions. The multiple choice instrument is given a score of 1 for the correct answer and a score of 0 for the wrong answer.

Data analysis techniques to see the effectiveness between the use of discovery-based worksheets in learning is done by analyzing the average value of the normalized gain with the n-Gain formula. The n-gain analysis that will be used in this study is based on the results of the pre-test and post-test. Hake (in Sundayana, 2015: 149) revealed that in order to know the effectiveness of a learning in conceptual understanding, an analysis of the average value of normalized gain was carried out.

\section{RESEARCH RESULTS AND DISCUSSION}

\subsection{Research Results Development of Student Worksheets Based on Discovery}

The results of the research and development of worksheets based on discovery obtained the following results.

\subsubsection{Research and Information Collecting}

Information gathering was carried out by observation and interviews with school principals and fourth-grade teachers of Public Elementary Schools in Way Halim District. The results of observations and interviews obtained information that (1) teachers do not understand about discovery learning and do not yet apply discovery learning in the classroom. (2) Teachers have not used the Student Worksheet that has practicum activities in the Student Worksheet that used. (3) the teacher states that with the Student Worksheet can facilitate the learning process in schools, especially in the sub-theme of the use of natural wealth in Indonesia (4) learning media such as the Student Worksheet need to be made that can be used to understand the concept of exploiting natural wealth in Indonesia (5) the teacher states that he agrees if the Student Learning Worksheet is developed based on discovery learning on the utilization of natural resources in Indonesia for student learning.

\subsubsection{Planning}

Planning is done by analyzing the results of information gathering. The product to be developed is a learning tool consisting of syllabus, lesson plans, student worksheets, and assessment instruments. Furthermore, the authors systematically compile the basic competencies, indicators, and learning objectives developed in this study. The theme and sub-theme specified is 'utilization of natural resources in Indonesia' in Class IV.

\subsubsection{Develop Preliminary Form of Product}

The steps in floating the worksheet products based on discovery learning are as follows. Discovery learning-based learning tool products that are developed are learning devices in class IV in sub-theme 2 'utilization of natural wealth in Indonesia'. Following are the initial product prototypes of the learning tools compiled. Syllabus, lesson plans, and student worksheets / worksheets (Cover, Preface, Table of Contents, Basic Competency Mapping, Instructions for Use, Material and Activity Description, Evaluation, Bibliography) and test instruments.

\subsubsection{Product Evaluation}

Product evaluation is the stage of testing the student worksheet that was designed. Evalusai was designed through expert validation, and students' responses through small class trials.

a. Material expert validation, design expert, and language expert validation

Judging from the feasibility of the material, every aspect assessed in the student worksheet that was developed was good enough to meet the eligibility criteria because the material used was based on $\mathrm{KI}$ and $\mathrm{KD}$, linguistic aspects were considered to have met the good linguistic criteria. Furthermore, in the aspect of presenting the images used in accordance with the level of knowledge of students, attracting students' interest, the cover used also represents the theme taken. The evaluation aspects are didactic, construction and technical requirements.

Based on the analysis of the results of the validation of media experts, the student worksheets that were developed can be said to be valid and can be implemented, although there are still a number of things that must be revised according to expert advice, including student worksheets that must be contextual with the surrounding environment, pictures on the contents Student worksheets should add the source.

b. Student responses through small group trials 
After passing the peer assessment feasibility test through an individual test that is declared feasible based on the feasibility test the use of student worksheets in learning according to the teacher's response, then testing is conducted to assess students' responses. The initial product trial through a small group test, intended to determine the response of students as users of student worksheets. The small group test sample was 6 students of class IV for each one class in SDN 2 perumnas way halim and one class in SDN 1 jagabaya which had low, medium, and high ability. The test was conducted by distributing questionnaires to respondents after the students were given learning treatment using student worksheets. The results of questionnaire data collection aims to determine the attractiveness, ease and usefulness of student worksheets in the opinion of students in the learning process. Questionnaire data filled in by students were then analyzed descriptively using a qualitative approach based on the percentage of poor $(\mathrm{K})$, good enough $(\mathrm{CB})$, good $(\mathrm{B})$ and very good $(\mathrm{SB})$ given. The results showed a very high level of student worksheet eligibility.

\subsubsection{Large Group Trial}

At this stage, the study was carried out again to test the validity, reliability, level of difficulty and different points of the items used as research instruments. Testing through the distribution of questions to fourth-grade students of elementary school 1 in Jagabaya. The questions used are adjusted to the indicators of achievement of learning objectives in the use of natural wealth in Indonesia. The test includes tests of validity, reliability, difficulty index and item differences that will be used. The validity test results show that all items are valid, can reveal data from the variables studied appropriately. 5 items had low-value validity $(16.66 \%), 16$ questions were of medium value $(53.33 \%)$, and 9 items were of high value $(30.00 \%)$.

The calibration of the instrument through the validity and reliability tests of these items shows valid and reliable questions to be used as research instruments. The spread of the level of difficulty of the questions was more dominated by questions that have an easy difficulty level of 4 items, while 24 questions were difficult and there were 2 items about the difficulty. While the test of distinguishing bad questions obtained based on the results of the students' work is 4 items with a tase of 30.0, and the different power of questions in the good category amounted to 17 with a percentage of $56.7 \%$. The test results are presented in the following Instrument Test Results table.

Table 1 test result

\begin{tabular}{|c|c|c|}
\hline Validity & Difficulty Index & Distinguishing Power \\
\hline $\begin{array}{c}\text { normal } \\
\text { (16 items) }\end{array}$ & $\begin{array}{c}\text { easy } \\
\text { (4 items) } \\
\end{array}$ & $\begin{array}{c}\text { bad } \\
(4 \text { items })\end{array}$ \\
\hline $\begin{array}{c}\text { strong } \\
(9 \text { items }) \\
\end{array}$ & $\begin{array}{c}\text { normal } \\
\text { (24 items) }\end{array}$ & $\begin{array}{l}\text { enough } \\
\text { ( } 9 \text { items) }\end{array}$ \\
\hline $\begin{array}{c}\text { low } \\
(5 \text { items })\end{array}$ & $\begin{array}{c}\text { hard } \\
(2 \text { items })\end{array}$ & $\begin{array}{c}\text { good } \\
(17 \text { items })\end{array}$ \\
\hline
\end{tabular}

\subsubsection{Main Field Testing}

The main test is carried out to test the effectiveness of the use of the Student Worksheet, the number of samples in this study was taken in two classes in the fourth grade Public Elementary School 2 national housing Way Halim. The cognitive effectiveness test of students is carried out using a control group design method that compares the situation of fourth grade A class who received treatment and fourth grade B class without treatment. The test is carried out by distributing multiple-choice questions related to learning materials that are used as instruments for testing the effectiveness of the use of Student Worksheets in achieving learning objectives. The results obtained from the initial conditions that tend to be the same, but the achievement of a significant gain shows the use of Discovery Learning Worksheets based on effective learning. The calculation of the gain value is based on the pretest and posttest data of students in the treatment class and the control class in full as shown in the following table.

Table 2. Comparison of the value of effectiveness of using Student Learning Worksheets based on discovery learning.

\begin{tabular}{|l|c|c|}
\hline Test Form & $\begin{array}{c}\text { Public Elementary School 2 Way } \\
\text { Halim National Housing } \\
\text { (Experiment Class) }\end{array}$ & $\begin{array}{c}\text { Public Elementary } \\
\text { School 1 Jagabaya } \\
\text { (Control Class) }\end{array}$ \\
\hline Pre-test & 51,25 & 46,78 \\
\hline Post-test & 90,73 & 62,67 \\
\hline Normalized Gain & 0,80 & 0,33 \\
\hline
\end{tabular}

Based on hypothesis testing, the differences in student learning outcomes based on the level of ability measured through gain values proved that the use of Discovery Learning Worksheet based on discovery learning with the theme of richness in my country can improve students' cognitive abilities. This test is intended to determine the level of effectiveness achieved from the use of Student Worksheets in classroom learning. This is proved by the increase in student learning outcomes as indicated by the gain value of students in the experimental 
class that is 0.80 which is greater than the gain value of the control class obtained 0.33 .

\subsubsection{Test of Attractiveness, Ease and Use of Student worksheets}

The test results obtained the value of the attractiveness of using student worksheets

based on the average value of attractiveness, convenience and usefulness of student worksheets in learning can be seen in the following table.

Table 3: Analysis of the Winning, Ease, and Utilization Analysis in the Use of Student Worksheets

\begin{tabular}{|c|c|c|c|c|c|c|}
\hline \multirow[b]{2}{*}{ No } & \multirow[b]{2}{*}{ Criteria } & \multirow[b]{2}{*}{$\begin{array}{l}\text { Assessment } \\
\text { Aspects }\end{array}$} & \multicolumn{2}{|c|}{ Student Assessment } & \multirow[b]{2}{*}{ Average } & \multirow[b]{2}{*}{$\begin{array}{l}\text { Rating } \\
\text { Category }\end{array}$} \\
\hline & & & $\begin{array}{l}\text { Public Elementary } \\
\text { School 2 Wayhalim } \\
\text { National Housing } \\
\text { (Experiment Class) }\end{array}$ & $\begin{array}{l}\text { Public } \\
\text { Elementary } \\
\text { School } \\
\text { Jagabaya } \\
\text { (Control Class) }\end{array}$ & & \\
\hline \multirow[t]{3}{*}{1} & \multirow[t]{2}{*}{ Attractiveness } & Cover & 3,71 & 3,72 & 3,71 & \multirow[t]{3}{*}{ Very high } \\
\hline & & Content & 3,60 & 3,69 & 3,65 & \\
\hline & \multicolumn{2}{|c|}{ Attractiveness Value } & 3,66 & 3,70 & 3,68 & \\
\hline \multirow[t]{3}{*}{2} & \multirow[t]{2}{*}{ Easiness } & Content & 3,67 & 3,68 & 3,67 & \multirow[t]{3}{*}{ Very high } \\
\hline & & Validity & 3,73 & 3,73 & 3,73 & \\
\hline & \multicolumn{2}{|l|}{ Easiness Value } & 3,70 & 3,70 & 3,70 & \\
\hline 3 & Usefulness & Function & 3,70 & 3,73 & 3,71 & Very high \\
\hline
\end{tabular}

Overall, an assessment of the usefulness of the Student Worksheets according to students' responses shows the use of the Student Worksheets is considered attractive, easy, and very useful in learning. This shows the recognition of students that the function of the Student Worksheet can help students to learn the material more easily in an effort to increase understanding of the concepts being learned.

\subsubsection{Effectiveness Test}

The product effectiveness test was conducted to see a significant improvement seen from the learning outcomes of students before and after learning using the Student Worksheet based on the discovery learning approach. NGain is used to analyze the increase in learning outcomes before and after learning by using the Learning Learning Worksheet based on discovery learning. The following are the results of the Pretest-Posttest Gain after being calculated and presented in table.

Table 4 N-Gain Results After Counting

\begin{tabular}{|l|c|c|c|}
\hline Public Elementary School 2 Way Halim National Housing & Pretest & Postest & \multirow{2}{*}{ Gain } \\
\cline { 2 - 3 } (Experiment Class) & \multicolumn{2}{|c|}{ Average } & \\
\hline Fourth grade A class (experiment) & 51,25 & 90,73 & 0,80 \\
\hline Fourth grade B class (control) & 46,78 & 62,67 & 0,33 \\
\hline
\end{tabular}

From table 4.6 it has been proven from the increase in student learning outcomes as indicated by the gain value of students in the experimental class is greater than the gain value of the control class. The average Gain results of the experimental class are higher at 0.80 which means normalized Gain is in the middle of clarification, so the level of effectiveness is effective.

\subsection{Discussion}

Discussion of the results of development research is based on the findings and studies that are observed during the research. The factor that has been observed in development research is The Development of Student Worksheets Based on Discovery Learning, Utilizing Natural Wealth Subtema in Indonesia in Fourth Grade Elementary Schools. In addition, the learning process that occurs in class when students solve problems on student worksheets also becomes a research observation.

\subsubsection{The Development of Student Worksheets Based on Discovery Learning, Utilizing Natural Wealth Subtema in Indonesia in Fourth Grade Elementary Schools}

Construction of student worksheets based on Discovery learning based on the concept of guided discovery learning. Inductive discovery strategies are based on thought processes in which students deduce from what is known to be true for specific things, will also be true for all things that are similar in general. Thus the student worksheet developed is the stage of presenting a statement of fact that acknowledges to support the conclusion so that students can practice the ability to think in finding solutions to the problems encountered. Development research is focused on developing student worksheets on the use of natural wealth in Indonesia class IV.

The preliminary study in this study was carried out by looking directly at the field and conducting observations, interviews, and distributing questionnaires to teachers and grade IV students at SDN 2 Perumnas Wayhalim and SDN 1 Jagabaya. (planning), based on research and information gathering related to the theme to be developed, which is to choose KI and KD class IV even semester with the theme of the use of natural wealth in Indonesia, and formulate indicators and learning objectives. Presentation of material packaged into student 
worksheets and evaluation based on indicators to achieve learning objectives. This discovery learning-based student worksheet with the theme of utilizing natural resources in Indonesia is organized into 6 lessons where each learning consists of several interrelated subjects.

Furthermore, the resulting student worksheets were then tested for eligibility through expert validation, one on one with the teacher / colleague, and limited trials to students as users. In general, the results of the validation of media experts and learning material experts stated that the student worksheets were good and could be used as teaching materials for students in grade IV elementary schools located around the city of Lampung.

The test results of the worksheet on the sub-theme of utilizing natural resources in Indonesia in learning were declared feasible. Thus the resulting student worksheets are ready to be implemented for the sake of real learning. According to research conducted by Sintia (2015: 15) this study states that developing student worksheets using discovery learning models that are interesting, easy and useful and effective for use as learning media. The stages of this research development begin from analyzing potentials and problems, collecting data, product design, design validation, design revisions, product trials, product revisions, and usage trials.

Based on the results of the study, the product developed obtained a score of attractiveness of 3.19 in the good category, an easy score of 3.20 in the good category and a benefit score of 3.38 in the very good category. The product developed was declared effective with a presentation of $79.41 \%$ of students completing the minimum completeness criteria.

\subsubsection{Product Interest, Ease and Use}

Developed Student Worksheets present theories, present problems and questions related to the material in an effort to achieve learning objectives. Based on the questionnaire data, in general, the test results obtained an average value of attractiveness of the Student Worksheet according to students is 3.68. This value is converted into the quality of the Student Worksheet is very interesting to use in learning. The ease of use of the Student Worksheets according to the students is worth 3.70, which means the quality of the Student Worksheets is declared very good. Furthermore, in terms of the usefulness of the Student Worksheets in the building based on discovery learning, students obtained 3.71 responses which also showed very useful quality. Based on the opinion of students as users obtained the value of the attractiveness of the Student Worksheet in learning as a whole is worth 3.70. This means that the Student Worksheet is good or appropriate for use in learning.

When compared with the results of the study according to Liansari (2015: 20) states that the results of this study aim to develop and test the feasibility, practicality, and effectiveness of Student Worksheets based on discovery learning and smart cards for human reproductive material for Eleven High Schools. The validity of the Student Worksheets and smart cards by material experts, media and field practitioners are 100\%, 83.3\%, 76.4\%, $100 \%, 80.5 \%$, and $77.7 \%$ respectively.

That shows the product is valid. Practicality tests with an average of positive answers to the Student Worksheet and smart cards were $87.6 \%$ and $95.52 \%$, respectively, indicating that the practical product was used. Products are considered effective because the learning outcomes of the aspects of knowledge, attitudes, and skills are 2.79 each; 3.41 ; and 3.43 greater Minimum completeness Criteria 2.67.

\subsubsection{Effectiveness of the Use of Student Learning Sheets Based on Discovery learning}

The effectiveness of the use of Discovery Learning Worksheets based on discovery learning with the sub-theme of the utilization of natural wealth in Indonesia for fourth-grade elementary school students is measured through student achievement. Assessment of learning achievement shows the high or low learning outcomes of students in learning graphic design materials using these learning media. This was stated by Reigeluth (2009: 77) that effectiveness refers to appropriate learning indicators (such as levels of achievement and specific fluency) to measure learning outcomes. In the cognitive aspect, the assessment of effectiveness includes knowledge, recognition, and understanding of the material, obtained from an increase in the gain value. Gain is a comparison of the difference between posttest and pretest against the maximum value.

The determination that the use of Student Worksheets in learning is said to be effective if the gain value is more than or equal to 0.7 which means achieving a high level of effectiveness. Effectiveness is determined based on a comparison between the learning outcomes of four elementary school students obtained based on the written test assessment of 30 multiple choice questions given to students before and after the use of the Student Worksheet. The initial hypothesis test was conducted to see the effect of the use of the Student Worksheets in improving the effectiveness of learning in the control class and the experimental class in Public Elementary School 1 Way Halim.

Starting with a t-test on the initial conditions of students conducted in the pretest test using the Independent Samples Test. The test was conducted on 32 fourth grade A class students (experimental class) who received treatment and 30 fourth grade B class students (control class) without treatment using Discovery Learning Worksheet based on discovery learning. The test results showed that the pretest value was not significantly different from the two classes as proved by statistical analysis, namely the count of 1.652 was smaller than the table of 2,0003 and the sig value of 0.104 was greater than a 5\%. Thus the initial conditions of students in the class groups tend to be the same and means that both classes can be used as objects of research on the effectiveness of the use of the Student Worksheet developed. 
The effectiveness test results of the use of Student Worksheets showed the level of effectiveness obtained by fourth grade A-class (treatment class) and four B class (untreated class) students in Public Elementary School 2 Way Halim, the average gain values obtained were 0,80 and 0,33 . This is proved from the increase in student learning outcomes as indicated by the value of the students gain in the experimental class is greater than the value of the control class gain.

Next, test the effectiveness of the use of the Student Worksheets for 30 fourth grade students at the Public Elementary School 1 Jagabaya. The learning implementation uses Student Worksheet as a result of the development carried out by different teachers. The effectiveness level of the use of the Student Worksheet based on the results of the value of the gain of fourth-grade students in the Public Elementary School 1 Jagabaya is 0.78 which tends to be the same as the treatment class in the Public Elementary School 2 Way Halim, which is 0.80. The results of this analysis show that the use of the Discovery Learning Worksheet based on learning for the theme of natural utilization in Indonesia has an impact on increasing the effectiveness of the same learning even though it is delivered by different teachers and different schools. A gain value of more than 0.7 indicates that the use of Discovery Learning Worksheets based on discovery has high effectiveness in improving the cognitive abilities of students.

\subsubsection{Research Limitations Development of student worksheets based on Discovery Learning}

The limitation in this study is that the development of student worksheets is only limited to one sub-theme, so it is considered to be less comprehensive in meeting students' needs. In addition, the competency test presented in the discovery learning based student worksheet with the theme of my richness is the sub-theme of the utilization of natural resources in Indonesia refers to indicators of achievement of learning objectives. But its weakness, the competency test in this material has not been presented in each of the basic competencies of each lesson. In addition, it is necessary to improve test questions that have distinguishing features about bad value. This research was conducted to focus on assessing the use of discovery learning-based LKPD in learning. Observations were made on increasing the attractiveness of using LKPD as an effort to increase the effectiveness of student learning outcomes. Meanwhile, instructional materials are not the only determinant of learning success, it is necessary to further study the effect of using learning methods and techniques designed to achieve learning objectives.

\section{CONCLUSION}

Based on the research results of the development of student worksheets based on discovery learning, it can be concluded as follows.

4.1 The realization of a worksheet product based on discovery learning that is feasible to use, after going through the validation process of the material, design, language, and practitioner validation, as well as the results of limited and extended trials of students as users, and can support the learning process well.

4.2 Observations on the attractiveness, ease, and usefulness of Student Worksheets in learning are measured based on the distribution of 62 questionnaires to fourth-grade students in two sample schools, which is Public Elementary School 2 Way Halim and Public Elementary School 1 Jagabaya, Bandar Lampung. The attractiveness of using Student Learning Sheets based on discovery learning in overall learning was 3.70. It can be concluded that the Student Worksheet is good or feasible to be used in learning that serves as a guide for learning to students so that they can learn effectively and efficiently used to support learning.

4.3 The effectiveness of the use of Discovery Learning Worksheets based on discovery learning with the theme of the richness of my country the sub-theme of the use of natural wealth in Indonesia for fourth-grade elementary school students is measured through student achievement, which is obtained from the assessment of the results of the gain value. Testing shows the level of effectiveness based on increasing student learning outcomes in four grade B class Public Elementary School 2 National Housing Way halim, obtained the value of students in the experimental class four grade A class is greater than the value of the control class gain, with an average value of 0.8334 and 0,3445 . This shows that the use of Worksheets based on discovery learning has high effectiveness in improving students' cognitive abilities.

\section{REFERENCES}

Abruscato,J \& DeRosa, d.a. 2010. Teaching Children science a discovery approach-7ed. Boston: Allyn \&Bacon. Amri, Sofan. 2013. Pengembangan \& Model Pembelajaran Dalam Kurikulum 2013. Prestasi Pustakarya: Jakarta. Balim, Ali Gunay. 2009. The Effects of Discovery Learning on Students' Success and Inquiry Learning Skills. Eurasian Journal of Educational Research. University Faculty of Education, Turkey. 35 : 1-20.

Borg \& Gall. 1989. Educational Research. Library of Congres Cataloging-in- Publication Data: New York.

Çelikler, Dilek. 2010. The Effect of Worksheets Developed for the Subject of Chemical Compounds on Student Achievement and Permanent Learning. Educational Research Association The International Journal of Research in Teacher Education. 1 (1) : 42-51.

Fibonacci, Anita. 2014. Development Fun-Chem Learning Materials Integrated SocioScience Issues To Increase Students Scientific Literacy. International Journal of Science and Research. 3 (11) : 708-713 
Forgarty, Robin. 1991. The Mindful School: How to Integrate the Curricula. United States of America. Skylight Publishing.Inc.

Gumay, Ali Balim. 2009. The Effects Of Discovery Learning on Students Sucess and Inquiry Learning Skills. Eurasian Journal of Education Research.35: 1-20.

Hamalik, Oemar. 2014. Perencanaan Pengajaran Bedasarkan Pendekatan Sistem. Bumi Aksara: Jakarta.

Ozman \& Yildrim. 2011. Effect of Worksheets on Student's Succes Acid and Based Sampel. Journal of Turkish Education. 2 (2) : 10-13

Reigeluth, C.M \& Chellman, A.C. 2009. Instructional-Design Theories and Models Volume III, Building a Common Knowledge Base. Taylor \& Francis. New York.

Samsul, Maarif. 2016. Improving Junior High School Students' Mathematical Analogical Ability Using Discovery Learning Method. International Journal of Research in Education and Science, Mathematics Education. Program of Muhammadiyah University Prof.DR.HAMKA, Indonesia 2 (1) : 114-124

Sundayana. 2015. Statistika Penelitian Pendidikan. Bandung: Alfabeta.

Supeno. 2008. Kapita Selekta Pembelajaran. Jakarta: Direktorat Jendral Pendidikan Tinggi Departemen Pendidikan Nasional.

Toman, Ufuk. 2013. Extended Worksheet Developed According To 5e Model Based On Constructivist Learning Approach. International Journal on New Trends in Education and Their Implications. 4 (4) : 173-183.

Trianto. 2010. Model Pembelajaran Terpadu. Bumi Aksara: Jakarta. 